\title{
INTERVIR NO PASSADO PERFORMANDO O TEMPO: ACHILLE MBEMBE E A CRÍTICA DA RAZÃO NEGRA
}

\author{
INTERVENE IN THE PAST BY PERFORMING THE TIME: \\ ACHILLE MBEMBE AND THE CRITIQUE OF BLACK REASON
}

\author{
Allan Kardec da Silva PEREIRA ${ }^{1}$
}

\begin{abstract}
Resumo: O estudo procura analisar a política do tempo presente no livro Crítica da Razão Negra, de Achille Mbembe (2014). Começaremos por delimitar o que seriam os impasses do tempo disciplinar da história, apontando como os conceitos de "feridas históricas" (Dipesh Chakrabarty), "passado irrevogável" (Berber Bevernage/ Vladimir Jankélévitch) conseguem propor alternativas a essa experiência do tempo. Diante da crise desse modelo de tempo disciplinar, faremos um breve apanhado bibliográfico argumentando a importância de pensar a dimensão performativa da escrita da história. Por fim, tomaremos Crítica da Razão Negra como um estudo de caso. Nossa hipótese é de que a escrita de Mbembe atua de maneira performativa por meio de metáforas e marcadores temporais como "O Negro", "devir-negro do mundo", etc. que remetem à temporalidade espectral de Jacques Derrida - como estratégia ético-política fundamental para o tempo presente.
\end{abstract}

Palavras-chave: Experiências do tempo; Performatividade; Achille Mbembe; Historiografia.

Abstract: The study seeks to analyze the politics of time present in Achille Mbembe's Critique of Black Reason (2014). We will begin by delimiting what would be the impasses of the disciplinary time of history, pointing out how the concepts of "historical wounds" (Dipesh Chakrabarty), "irrevocable past" (Berber Bevernage / Vladimir Jankélévitch) can propose alternatives to this experience of time. Faced with the crisis of this model of disciplinary time, we will make a brief bibliographical review arguing the importance of thinking the performative dimension of the writing of history. Finally, we will take Critique of Black Reason as a case study. Our hypothesis is that Mbembe's writing acts in a performative way through metaphors and temporal markers such as "The Black," "becoming-black of the world," etc. - which refer to the spectral temporality of Jacques Derrida - as a fundamental ethical-political strategy for the present time.

Keywords: Experiences of time; Performativity; Achille Mbembe; Historiografia.

"A ideia de um progresso da humanidade na história é inseparável da ideia de sua marcha no interior de um tempo vazio e homogêneo. A crítica da ideia de progresso tem como pressuposto a crítica da ideia dessa marcha" (Walter Benjamin, 1994, p. 229).

“Há uma 'inquietante familiaridade' desse passado que um ocupante atual rechaçou (ou acreditou ter rechaçado para apropriar-se de seu lugar). O morto

\footnotetext{
* Doutorando em História - Programa de Pós-Graduação em História - UFRGS - Universidade Federal do Rio Grande do Sul. Porto Alegre, RS - Brasil. Bolsista CAPES. Email: allankardec_vdb@hotmail.com 
assombra o vivo; ele re-morde (mordida secreta e repetida)" (Michel de Certeau, 2011, p. 71).

\section{I - Impasses no tempo disciplinar}

A história é um fazer, uma operação. Acrescentaríamos: uma performance. Michel de Certeau, acima citado, como poucos, enfatizou essas dimensões. Ele recordava o quanto a historiografia desenvolveu-se "em função de um corte entre o passado e o presente". Sendo um resultado das relações de saber e de poder entre dois lugares:

(...) por um lado, o lugar presente (científico, profissional, social) do trabalho, o aparato técnico e conceitual da pesquisa e da interpretação, a operação de descrever e/ou explicar; e, por outro, os lugares (museus, arquivos, bibliotecas) em que são guardados, inertes, os materiais que são objeto da pesquisa $\mathrm{e}-\mathrm{em}$ um segundo momento deslocados no tempo - os sistemas ou acontecimentos do passado, cuja análise é permitida por intermédio desses materiais. Uma fronteira separa a instituição atual (que fabrica representações) das regiões antigas ou longínquas (encenadas pelas representações historiográficas) (CERTEAU, 2011, p. 72).

Havia, portanto, o estabelecimento de uma diferença (o "corte" de que ele fala), ou mesmo uma hierarquia entre o presente e o passado, entre o historiador e seu objeto. Esse modelo de disciplinarização do conhecimento histórico teve no século XIX e o projeto do nacionalismo europeu seu momento de afirmação. Wendy Brown recorda que a convicção de que a história tem um por que, um propósito e uma direção seria fundamental ao projeto da modernidade. Algo que era pensado, sobretudo, por meio de uma dimensão temporal: a modernidade teria emergido ela própria de "um tempo primitivo, religioso, ligado a castas e aos parentescos, não igualitário e não emancipado, sangrento, um tempo escuro e sem Estado". Sua correspondente dimensão espacial supunha que a Europa seria o centro dessa aparição, e que as outras partes do globo deveriam (em diferentes graus) almejar essa condição. Em sua dimensão política, a modernidade estaria estruturada em seu interior pela ideia de progresso ilimitado. Preceito fundamental da Ilustração, esse conceito de progresso teria sido gestado de diferentes formas a partir dos séculos XVIII e XIX. Em Hegel, o mundo se transformava em cada vez mais racional; em Kant, cada vez mais pacífico; em Thomas Paine, cada vez mais conformado aos princípios do direito natural; para Tocqueville, 
cada vez mais igualitário; para Stuart Mill, cada vez mais livre e razoável; para Marx, todas essas coisas de uma vez (BROWN, 2014, p. 22-23)i.

Nesse sentido, Maria Inés Mudrovcic recorda como a historiografia moderna surge a serviço de uma ideia de nação tendo como objetivo, nos dizeres de Ernest Renan, construir uma ponte entre um passado glorioso que os cidadãos "construiriam juntos" e um presente desejoso de "realizar juntos". Diferenciando-se da prática de retóricos e amadores que predominou até o século XVIII, a história torna-se uma "disciplina profissional" durante o século XIX. Baseada em critérios de objetividade, desejando estar separada de quaisquer orientações ideológicas, essa disciplina histórica narrará as origens dos estados-nação as quais estaria aliançada (MUDROVCIC, 2012, p. 25). Para Arthur Ávila, esse modelo disciplinar foi tributário da expansão imperial europeia tão em voga no século XIX. Enquanto poderosa ferramenta ideológica, a história atuava através de marcadores temporais, ou seja, a utilização de termos como "civilização", "progresso", "atraso", "desenvolvimento" etc. que objetivavam marginalizar e/ou apagar outras modalidades de conceber o passado em suas distintas relações com o presente (ÁVILA, 2016, p. 193).

Todavia, como bem lembrou Hayden White, esse modelo de orientação temporal e disciplinar da história entraria em crise no século XX, num contexto de:

acontecimentos que não só não poderiam ter ocorrido antes do século $\mathrm{XX}$, mas que, por sua natureza, alcance e implicações, nenhuma idade prévia sequer poderia tê-los imaginado. Alguns desses acontecimentos - como as duas Guerras Mundiais, um crescimento até então inimaginável da população mundial, pobreza e fome numa escala jamais experimentada antes, a poluição da ecosfera por explosão nuclear, a disponibilidade indiscriminada de contaminantes, programas de genocídio levados a efeito por sociedades, através da utilização de tecnologia científica e procedimentos racionalizados de governo e de guerra (dentre esses, o genocídio de 6 milhões de judeus europeus perpetrado pela Alemanha é paradigmático) - funcionam na consciência de certos grupos sociais exatamente como traumas infantis são concebidos para funcionar na psique de certos indivíduos neuróticos. Isso significa que não podem ser simplesmente esquecidos ou tirados da cabeça, nem, por outro lado, adequadamente lembrados, isto é, identificados claramente e sem ambiguidade quanto a seu significado, e contextualizados na memória do grupo, de forma a reduzir a sombra que projetam sobre a capacidade do grupo de entrar em seu presente e visualizar um futuro livre de seus efeitos debilitantes. (WHITE, 1999, p. 196).

Ora, esses "efeitos debilitantes" dos eventos modernistas de que fala Hayden White terminaram por abalar a supostamente natural separação entre passado e presente. 
Para Chris Lorenz, a partir da década de 1990, percebe-se uma agenda emergente na teoria da história, principalmente ligada ao que Andreas Huyssen chamou de memory boom (HUYSSEN, 2000). Ao lado de preocupações que ocupavam os teóricos da história desde o pós-Segunda Guerra Mundial - a questão da explicação e da representação histórica - ganha destaque mais três problemáticas: 1) a questão do "Outro"; 2) a questão do passado traumático; 3) a questão do uso da linguagem como forma de ação. No primeiro ponto, deu-se atenção aos sujeitos de representação e seus diferentes códigos representacionais. Influenciado tanto pelo multiculturalismo, quanto pelo pós-modernismo, há um "descentramento" do self unitário em uma variedade de selfs-coletivos - como gênero, raça, etnia, colonialismo e classe. No que diz respeito ao segundo desdobramento, sob a influência dos estudos de memória, o foco mudou para experiências traumáticas no passado. Na trilha dos estudos do Holocausto, essas pesquisas tinham uma ênfase na perspectiva das vítimas, de maneira que podem ser vistas como uma extensão das abordagens da history from below ["história vista de baixo"] que focaram em questões sociais, de gênero, subalternidade e micro-história a partir dos anos 1970. Já a terceira dimensão refere-se à influência da análise do discurso de Foucault, além do caráter performativo da linguagem (baseado nos trabalhos de J.L.Austin e John Searle). Ambas as correntes acreditam que o uso da linguagem não é somente um meio de representação, mas também, uma forma de ação/prática social (LORENZ, 2015, p. 26-27).

Nesse momento, intensificam-se na produção acadêmica trabalhos que refletem a luta por reconhecimento e justiça de grupos que mesmo em contextos pós-coloniais ${ }^{\mathrm{ii}}$, ou pós-ditatoriais, ainda viam pairar sob o presente globalizado a ameaça da espoliação e vulnerabilidade. Daí porque, seja tão importante para compreender essa implicação ético-política da escrita histórica a noção de ferida histórica (historical wound) desenvolvida por Dipesh Chakrabarty (2007) no artigo History and the politics of recognition. Para o autor, a retórica e o espírito de descolonização das décadas de 1950 e 1960 contribuiram para que determinados grupos marginalizados e oprimidos buscassem políticas democráticas de reconhecimento e reparação de injustiças sofridas no passado. Ele cita como exemplo os povos aborígenes da Austrália, Nova Zelândia e Canadá, além dos anteriormente “intocáveis" na Índia - agora denominados dalits.

Para Chakrabarty, as feridas históricas seriam distintas das verdades históricas, embora estas fossem uma condição de possibilidade para as primeiras. Enquanto as verdades históricas são sempre verificáveis do ponto de vista dos métodos de pesquisa 
disciplinar, as feridas históricas, por outro lado, seriam "uma mistura de história e memória". Nesse sentido, a condição performativa do discurso histórico torna-se algo estratégico no que diz respeito às políticas de reconhecimento e reparação. $\mathrm{O}$ autor toma como exemplo o ato de chamar (na década de 1990) as gerações de crianças aborígenes que foram removidas da custódia dos pais tanto pelo governo colonial australiano, quanto por grupos missionários, de "geração roubada" para demonstrar um episódio em que uma ferida histórica havia sido performativamente operacionalizada. Chakrabarty recorda que a remoção de crianças aborígenes era uma verdade histórica, ou seja, uma generalização aberta à verificação empírica da historiografia disciplinada. Mas que nesse contexto, o termo "roubada" deu à situação uma intensidade emocional que a escala dos historiadores disciplinares certamente não conseguiria mensurar. Assim, a popularidade imediata dessa ferida histórica nos anos 1990 deveu-se a um consenso social emergente sobre a situação histórica dos aborígenes. O que implica que essas feridas históricas não sejam formações permanentes, haja vista que o consenso social em que se baseiam está sempre aberto a novos desafios, podendo ser desfeito de acordo com outros direcionamentos políticos, sociais etc. (CHAKRABARTY, 2007, p. 77-78). Como sustenta Chris Lorenz, uma vez que o reconhecimento dessas injustiças também depende do reconhecimento de direitos humanos universais, as "feridas históricas" apontam para a estreita interdependência da história, do direito, da política e da ética (LORENZ, 2015, p. 31). Por último, as feridas históricas geralmente impõem um desafio para a disciplina da história ao privilegiar aparentemente o acesso "experiencial" ao passado, na medida em que questiona os tradicionais pressupostos sobre "distância" e "objetividade histórica".

Essas questões ganharam bastante relevância no debate acerca do trabalho de historiadores nas chamadas comissões da verdade em países que passaram por regimes ditatoriais. Certamente, o livro Historia, memoria y violencia estatal. Tiempo y Justicia, de Berber Bevernage (2015), aparece como um estudo de fôlego que desenvolve interessantes considerações sobre as dimensões temporais da relação entre história, justiça e ética.

Para Bevernage, as políticas do tempo que advogam uma ideia de passado como distante/ausente tornam-se problemáticas em situações em que o "dever de recordar" ou a obrigação de "fazer justiça ao passado" se impõem como requisito democrático essencial. Isso fica claro, segundo o autor, quando contrastamos o modelo de tempo da história disciplinar com a noção de tempo geralmente implícita no discurso judicial: 
(...) o discurso judicial pressupõe um tempo reversível, em que o crime está, por assim dizer, totalmente presente e pode ser revertido, anulado, ou compensado pela sentença correta e castigo. Esta noção de tempo se relaciona a uma lógica quase-econômica de culpa e castigo, no qual a justiça é ultimamente entendida como retribuição e ressarcimento. Contrastando com isso, a história tradicionalmente trabalha com o que já sucedeu e agora está irremediavelmente perdido. Insiste na "flecha do tempo",iii, pensa o tempo como fundamentalmente irreversível, e nos força a reconhecer as dimensões de ausência e inalterabilidade do passado. (BEVERNAGE, 2015, p. 23)

Que o passado sobreviva de alguma forma, que ele mantenha alguma presença, é uma primeira conclusão possível nesse momento. Mas, Bevernage acredita que ainda persista aqui uma aporia, pois, ao repensar o tempo irreversível da história com seus enfoques na ausência/distância do passado, como não cair na "reversibilidade mítica" do tempo judicial? Como conceber uma "terceira via" que resista à polarização irreversível $\mathrm{X}$ reversível?

Para o autor, as considerações sobre tempo e temporalidade do filósofo francês Vladimir Jankélévitch oferecem um bom ponto de partida, ao propor uma distinção analítica entre o "irreversível” e o que ele chama de "irrevogável”:

Embora ambos, segundo Jankélévitch, são dimensões do mesmo processo temporal, se referem a duas experiências do passado radicalmente diferentes. O irreversível, um ter-tido-lugar (avoir-eulieu) que deveria ser primariamente transcrito como um ter-sido (avoir-été), se refere a um passado transitório e efêmero. $\mathrm{O}$ irrevogável, um ter-tido-lugar comumente associado com o ter-sidofeito (avoir-fait), pelo contrário, é teimoso e difícil. As pessoas experimentam o passado como irreversível quando o sentem como frágil e imediatamente dissolúvel ou fugaz em relação ao presente. Porém, segundo Jankélévitch, ambas as experiências do passado se relacionam a uma impossibilidade inversa: a de revisitar um passado perdido ou de expelir um passado extemporâneo; trazer um passado demasiado passado (um passé trop passé) ao presente ou desterrar um passado demasiado presente (um passé trop presente) desse presente. (BEVERNAGE, 2015, p. 26)

Longe da dicotomia do absolutamente ausente $\mathrm{x}$ absolutamente presente, o irrevogável, portanto: "refere-se à presença incompleta e aparentemente contraditória do que em geral se considera ausente, a saber, o passado" (ibidem, p. 27).

Partindo desses pressupostos, por qual motivo diferentes grupos recorreram ao discurso histórico como ferramenta ética e política? As hipóteses sobre o regime de 
historicidade $^{i v}$ presentista, de Fraçois Hartog (2013), oferecem um importante diagnóstico da situação. Remontando às considerações do historiador alemão Reinhart Koselleck, para quem o tempo histórico é produzido pela distância entre um "campo de experiência" e um "horizonte de expectativa", Hartog vai questionar se há, então, uma crise no regime de historicidade moderno, que teria dado origem ao qual ele nomeia de presentismo. Ou seja, uma nova configuração do tempo, marcada por um "presente perpétuo, inacessível e quase imóvel”v (HARTOG, 2013, p. 39).

Todavia, Hartog ressalva que esse presente presentista é vivenciado de formas distintas conforme o lugar ocupado pelos indivíduos na sociedade. Pode tanto ser percebido como um tempo de fluxos, da aceleração e de uma "mobilidade valorizada e valorizante", ou seja, como o tempo da globalização e do novo espírito do capitalismo ${ }^{\text {vi, }}$ quanto precário, transitório, desacelerado, sem passado e sem futuro real (ibidem, p. 1415). Sendo assim, operacionalizar conceitos como "feridas históricas" ou "passados irrevogáveis" deve ser visto como uma estratégia, uma reação ética possível ao presentismo.

Essas questões permitem compreender uma perspectiva historiográfica que excede normas da disciplina histórica quanto à representação, temporalização e busca de verdade imparcial e nos remete a um questionamento levantado no livro Breaking up Time, escrito por Chris Lorenz e Berber Bevernage: "a distinção entre passado e futuro é antes uma questão de "observar" as distinções que são "dadas" ou envolve uma postura mais ativa na qual os atores sociais criam e recriam essas distinções temporais?". Ou seja, é permitido pensar a atuação dos historiadores com relação ao passado apenas enquanto reflexão, ou nosso relacionamento com o passado envolve também tipos específicos de “intervenção performativa”? (LORENZ; BEVERNAGE; 2013, p. 29-30).

\section{II - O giro performativo da história}

Especialmente na segunda metade do século XX, o interior das humanidades e ciências sociais vai ser marcado por giros (linguístico, cultural, antropológico, visual, ético-político etc.). Dentro desses recortes teóricos, o giro performativo pode ser visto como uma "reformulação do giro linguístico" (SÁNCHEZ-PRIETO, 2013), ou mesmo como algo comum a diversas outras disciplinas (BURKE, 2004). 
Uma obra seminal nesse debate, certamente, é Quando dizer é fazer (1992), do filósofo da linguagem britânico John Austin, escrito em 1962. Nele o autor desenvolve a teoria dos atos de fala, que estabelece uma distinção entre enunciados de ação, os performativos (a linguagem é utilizada para fazer algo e não apenas dizer algo, como demonstram atos de inauguração, vereditos, promessas) e atos constatativos, que apenas informam ou constatam algo, seja verdadeiro ou falso. Nesse sentido, os performativos não devem ser pensados a partir das categorias de verdade ou falsidade, mas sim em função de seu êxito ou fracasso em se realizar. Como observado por Sánchez-Prieto, a filosofia analítica de Austin recupera a ação, preterida pelo estruturalismo (SÁNCHEZPRIETO, 2013, p. 05).

Austin seria uma grande referência para o historiador britânico Quentin Skinner, que procurou pensar a filosofia política a partir da teoria dos atos de fala, onde atores específicos (é clássica suas reflexões sobre alguns nomes do pensamento político moderno, tais como Maquiavel, Dante, Bodin, Lutero etc.), atuavam em resposta a conflitos específicos e dentro de linguagens próprias ao tempo em que aquelas ideias foram desenvolvidas. Dessa forma, ao produzir teoria política, aqueles autores estariam se inserindo em uma arena de polemizações cujo objetivo seria definir a superioridade de determinados conceitos, criando aliados e opositores, e tentando a realização prática de suas ideias (JASMIN, 2005, p. 28).

$\mathrm{Na}$ historiografia, Peter Burke, em O que é história cultural? - livro cuja primeira edição data de 2004 - talvez tenha sido o primeiro historiador a falar de forma mais incisiva sobre um giro perfomativo da história. Para ele, os historiadores vinham mudando do enfoque de "roteiro" para "performance" social, termo que tinha sido desenvolvido inicialmente na década de 1970, por antropólogos que trabalhavam com rituais e fofocas, e com o antropólogo Marshall Sahlins. Para Burke, esses estudos voltados ao performativo provocavam uma "revolução silenciosa na prática acadêmica da área de humanidades", a qual chama de "ocasionalismo"vii. (BURKE, 2008, p. 119).

Aprofundada um ano depois no texto Performing History: The Importance of Occasions, as interpretações de Burke buscará compreender de que forma os pesquisadores percebiam rituais, festivais, identidades, gêneros, obras arquitetônicas enquanto performances. $\mathrm{O}$ foco aqui parece ser mais a sociedade e não exatamente a prática historiográfica (BURKE, 2005).

Outra contribuição recente ao debate é o artigo Performing History: How Historical Scholarship is Shaped by Epistemic Virtues, do historiador holandês Herman 
Paul (2011). Para o autor, os filósofos da história das últimas décadas se interessaram predominantemente na produção (publicada) do conhecimento histórico - aqui ele faz uma referência especial à Meta-História, famosa obra que Hayden White escreveu em 1973 - e ignoraram que a erudição histórica vai além, sendo uma prática de leitura, pensamento, discussão e escrita, cuja performance exige "o cultivo ativo de certas habilidades, atitudes e virtudes". Essas "culturas epistêmicas", todavia, são contingentes, sendo motivo de disputas/reinterpretações entre os historiadores". Aparentemente, Herman Paul concentra sua análise da dimensão performativa dos historiadores menos na forma de como eles fragmentam o tempo, ou mesmo criem passados possíveis, e termina por se deter mais em explorar suas performances em salas de leitura de arquivos, entre pilhas de bibliotecas, e em estudos desordenados com notas (PAUL, 2011, p. 1).

Desta feita, de maior amplitude seria a introdução ao livro Performing the Past: Memory, History, and identity in Modern Europe ${ }^{\text {viii }}$, escrita por Jay Winter (2010). O historiador americano inicia discutindo o que seria uma memória performada:

\begin{abstract}
A memória performada é o coração da memória coletiva. Quando indivíduos e grupos expressam, encarnam, interpretam ou repetem um roteiro sobre o passado, eles galvanizam os laços que unem grupos e depositam traços de memória adicionais sobre o passado em suas próprias mentes. Essa memórias renovadas e restauradas variam frequentemente e superam memórias anteriores, criando um palimpsesto complexo sobre o passado que cada um de nós carrega conosco (WINTER, 2010, p. 11)
\end{abstract}

A dinâmica entre memória coletiva e memória individual aqui é utilizada para pensar o quão performado pode ser o passado. Remetendo à teoria da performatividade dos atos de fala, de J. L. Austin, Jay Winter ressalta o quanto o ato performativo "descreve uma condição e a recria", ou seja, rememorar um passado é também, ao mesmo tempo, adicionar traços próprios à história inicial (ibidem, p. 11). Jay Winter conclama para que os historiadores cada vez mais atentem para as maneiras como as pessoas constroem seu sentido da história ao performar o passado. Além disso, interessa ao autor nesse momento: reconhecer de que forma os próprios historiadores também se envolvem em algum tipo de performatividade (ibidem, p. 21-22).

Partindo de premissas semelhantes, mas detalhando alguns estudos de caso, o historiador belga Berber Bevernage no livro Historia,memoria y violencia estatal Tiempo y justicia (2015) explora como o tempo é performado em contextos das 
chamadas "Comissões da Verdade" instauradas em regimes pós-ditatoriais de países como África do Sul, Serra Leoa e Argentina. Questionando a neutralidade da disciplina histórica, Bevernage é mais um a tomar John Austin como referência para pensar de que maneira a linguagem histórica é utilizada não apenas para descrever uma realidade (a dimensão "constatativa" da linguagem, que havíamos comentado), mas também para produzir efeitos sociopolíticos e que, até certo ponto, pode levar a efetivação de um estado de coisas que pretende meramente descrever (a dimensão "performativa" da linguagem). (BEVERNAGE, 2015, p. 48).

Nesse sentido, interessa a Bevernage mostrar como a tentativa performativa de “distanciar" o passado, de reforçar/impor uma ruptura entre o passado e o presente é estratégica para países que atravessam transições. Essa relação entre políticas do tempo (ele aqui faz referência ao trabalho de Peter Osborne) e projeto nacional é percebida por Bevernage na linguagem histórica utilizada no apêndice da constituição provisória sulafricana de 1993, que arranjou a anistia e criou espaço para a futura TRC (Truth and Reconciliation Comission). Termos e frases como "ponte histórica”, "base sólida (...) para transcender (...) o legado de ódio, medo, culpa e vingança", "prazo final", ou mesmo o uso de "povo sul-africano" na primeira pessoa do plural, são vistos como expressões performativas essenciais ao projeto de construção nacional da "nova" África do Sul. (ibidem, p. 117-118).

Porém, segue Bevernage, esse projeto de identidade nacional sul-africana, construído em uma "historicidade descontínua", terminava por esconder um passado do Apartheid que não queria passar. Por esse motivo, o autor destaca a atuação do Grupo de Apoio Khulumani, único movimento social sul-africano a representar vítimas e sobreviventes do Apartheid. Bevernage nota como esse conflito político e essas demandas éticas, decisivas ao futuro da nação sul-africana, era travada por meio de marcadores temporais. Os Khulumani negavam-se ao "encerramento", à "recuperação". Contrariamente ao "modelo terapêutico da historiografia" adotado pelo TRC, o grupo Khulumani insistia na situação das vítimas que ainda sofriam e não tinham se recuperado. Desafiando o tempo irreversível da história nacional, negavam, pois, a distância entre presente e passado. (ibidem, p. 122-126) ${ }^{\mathrm{ix}}$.

Remetendo aos impasses do tempo disciplinar que comentávamos no primeiro tópico desse texto (a descrença na concepção moderna de tempo, com sua divisão restrita entre passado e presente), Bevernage acredita que a grande parte da historiografia, no contexto da explosão de memórias traumáticas, terminou por adotar 
uma temporalidade convencional. Daí porque seja importante, acredita o autor, nos aproximar da dimensão performativa do discurso histórico:

Mais que meramente descritivos ou analíticos, os discursos sobre a história tendem a produzir efeitos sócio-políticos significativos. No campo da justiça transicional, esta performatividade se manifesta como uma tendência a restaurar ou criar uma ruptura entre o passado e o presente reforçando ou impondo um sentido de "distância" temporal, e em algumas ocasiões também se transforma em uma prática "alocrônica" [o termo aqui vem do antropólogo Johannes Fabian] que posiciona simbolicamente as pessoas no tempo e os etiqueta como anacronismos viventes. Pensemos na África do Sul (...) onde a constante ênfase na "novidade" da nação tendia a ser acompanhada pela exclusão de vítimas específicas, cuja luta passou a ser associada com o passado e com o "velho". Nenhum desses fenômenos (a performatividade dos discursos históricos e seu potencial alocrônico) tem recebido a atenção acadêmica que merece. Seria interessante rastreá-los em outros reinos sociais para além da esfera das comissões da verdade e da justiça transicional (BEVERNAGE, 2015, p. 296297).

Seguindo a proposta de Bevernage, basta pensarmos o quanto o discurso do presidente americano Donald Trump de "Tornar a América Grande Novamente" utilizase de uma prática alocrônica ao remeter a um possível "passado grandioso" que seria necessário retomar novamente (de fato, é o termo again o marcador temporal e discursivo decisivo dessa frase) para inaugurar um novo tempo pós-Obama. Uma referência ao passado que muitos críticos trataram de evidenciar seu caráter conservador, reacionário e até mesmo racista: "uma ação temporal em que o futuro se torna mais próximo com o passado e menos como o presente" (MIRZOEFF, 2017).

Nesse momento repleto de eventos limites, passados traumáticos e as constantes demandas sociais por história, pensar a atuação dos historiadores torna-se um desafio ético e político de primeira ordem. Respondendo o questionamento lançado por Berber Bevernage e Chriz Lorenz (2013) que encerra nosso primeiro subtópico, percebemos que entender a relação dos historiadores com o passado apenas enquanto reflexão termina por subestimar sua capacidade de intervir sobre esse mesmo passado. Do mesmo modo, ao destacarmos como o discurso histórico pode intervir performativamente, especialmente em sua capacidade de fragmentar o tempo (breaking up time) tenderemos a entender melhor o lugar estratégico de um livro como Crítica da Razão Negra, de Achille Mbembe. 
Desde os primeiros parágrafos de Crítica da Razão Negra, percebemos o tom de manifesto que Achille Mbembe ${ }^{\mathrm{x}}$ projeta ao livro, declarando que a Europa deixou de ser o centro de gravidade do mundo ${ }^{x i}$. Nesse mesmo parágrafo, há também uma indicação direta do caráter performativo de sua empreitada ao afirmar que seu objetivo era “escrever este livro à semelhança de um rio com seus muitos afluentes" (MBEMBE, 2014, p. 9). Ao ser indagado sobre seu modo de escrita por Arlette Farge, Mbembe articula as opções estéticas por ele tomadas a uma tentativa de dizer a África "de uma forma que não seja repetição pura e simples". O que explicaria sua escrita figural, vertiginosa, dissoluta, dispersiva. Uma escrita, em suas palavras, "feita de anéis entrecruzados e cujas arestas e linhas se juntam no ponto de fuga” (BUALA, 2013).

Palavras que performatizam um sentido de urgência, ou mesmo de revelação. Crítica da Razão Negra, já na escolha do título, almeja inverter o polo da Crítica da Razão Pura - uma das obras centrais do Iluminismo, escrita por Immanuel Kant em 1781 -, na medida em que desenvolve o que seria o "devir-negro do mundo", ou seja, a ideia de que $O$ Negro não mais se relaciona apenas às pessoas de origem africana do primeiro capitalismo. Para Mbembe, no contexto de avanço do neoliberalismo atual (que ele considera como uma "religião animista"), O Negro designa toda uma parcela da humanidade espoliada pelo capital, ou seja, há uma universalização da condição negra, onde os riscos sistêmicos aos quais somente os escravos negros foram expostos passam a tornar-se quando não a norma, ao menos a situação de grande parte dos grupos subalternos. Que o termo Negro seja destacado, na grande maioria do texto, em itálico e maiúsculo, só ressalta a amplitude do projeto teórico de Mbembe. Importa aqui uma escrita que reflita o caráter emergente do tempo de agora, com seus riscos e potenciais que abrem possibilidades únicas ao pensamento crítico (MBEMBE, 2014, p. 9).

Mbembe vai até o primeiro momento do capitalismo, o momento em que $O$ Negro foi inventado, e trata de demonstrar as proximidades da forma de experienciar o tempo daqueles sujeitos com a maneira de perceber o novo tempo do mundo ${ }^{\mathrm{xii}}$ dos povos precarizados do mundo atual. Ao recordar como funcionava a fabricação das questões de raça na América (o que ele chama de aquela "destituição cívica" dos escravizados), Mbembe faz questão de usar as seguintes definições: "funcionava por meio de um processo de servidão perpétua"; "Os Negros e os seus descendentes serão, desde então, 
comprados para sempre" (ibidem, p. 42) como forma de demonstrar seu caráter descartável e solúvel, institucionalizado enquanto padrão de vida. Nesse sentido, os Negros escravizados eram confrontados com uma perda de ordem genealógica, na medida em que no Novo Mundo, estariam juridicamente destruídos de quaisquer parentescos. A violência aqui, recorda Mbembe, possuía uma tripla dimensão, operando em três tempos:

É "violência no comportamento cotidiano" do colonizador a respeito do colonizado, "violência a respeito do passado" do colonizado, "que é esvaziado de qualquer substância", e violência e injúria a respeito do futuro, "pois o regime colonial apresenta-se como eterno" (MBEMBE, 2014, p. 183).

Desprovidos de passado e com um futuro de espoliação perpétua, os Negros viverão um presente eterno, uma humanidade prorrogada, na condição de eterna luta para sair da fixação/repetição laboral. Ou seja, ao controle dos corpos juntava-se um controle do tempo dos negros escravizados: passado, presente e futuro.

Porém, apesar de tudo, Mbembe recorda o quanto o nome negro liberou, "durante muito tempo", uma energia extraordinária:

É próprio desta humanidade prorrogada, incessantemente condenada a reconfigurar-se, anunciar um desejo radical, insubmersível e vindouro, de liberdade ou de vingança, principalmente quando tal humanidade não passa pela abdicação radical do sujeito. Com efeito, ainda que juridicamente definidos como bens móveis e apesar das práticas de crueldade, de degradação e de desumanização, os escravos continuam a ser humanos (MBEMBE, 2014, p. 91).

Dupla condição: ora como fonte de instintos ferozes e forças caóticas, ora como signo luminoso da possibilidade de redenção do mundo e da vida:

\footnotetext{
Mas - e esta é a sua manifesta dualidade -, numa reviravolta espectacular tomou-se o símbolo de um desejo consciente de vida, força pujante, flutuante e plâstica, plenamente engajada no acto de criação e até de viver em vários tempos e várias histórias ao mesmo tempo (MBEMBE, 2014, p. 19).
}

Percebe-se o quanto Mbembe usa de marcadores temporais em toda a linguagem da obra. Seu discurso assume um tom ensaístico com sua abordagem macroestrutural e seu diminuto investimento em explanações empíricas de sua tese (algo que fica legado à farta indicação bibliográfica). Importa ao projeto teórico em torno do devir-negro do 
mundo de Mbembe trazer à parcela subalterna da humanidade uma promessa. Ou seja, quando Mbembe retoma o termo $O$ Negro, que pertence à fase do primeiro capitalismo, não é apenas para questionar o caráter "inventado" do mesmo. Mas é uma forma de intervir ético e politicamente no tempo histórico, de moto a captar uma força "capaz de transformar e assimilar o passado, de curar as mais terríveis feridas, de reparar as perdas, de fazer uma história nova com acontecimentos antigos” (MBEMBE, 2014, p. $55)$.

Ainda mais decisivo no que diz respeito à dimensão performativa da história, é quando Mbembe estabelece uma distinção entre uma "primeira escrita", do colonizador (a qual ele chama de "razão negra do mundo"), e uma "segunda escrita", do colonizado. A primeira escrita seria um julgamento de identidade, que caracterizaria a percepção que o Ocidente tinha do Negro, enquanto a segunda escrita seria uma declaração de identidade, momento em que o Negro "diz de si mesmo que é aquilo que não foi apreendido; aquele que não está onde se diz estar" (ibidem, p. 59). Para fugir aos predicados identitários impostos pelo regime laboral da escravidão, era preciso inventar formas de resistir a essa imposição temporal. Nesse sentido, num contexto pós-colonial, a escrita:

esforça-se, aliás, por edificar uma comunidade que se forja a partir de restos dispersos em todos os cantos do mundo. No Ocidente, a realidade é a de um grupo composto por escravos e homens de cor livres que vivem, na maior parte dos casos, nas zonas cinzentas de uma cidadania nominal, no meio de um estado que, apesar de celebrar a liberdade e a democracia, é, fundamentalmente, um estado esclavagista. Ao longo deste período, a escrita da história tem uma dimensão performativa. A estrutura de tal performance é de ordem teológica. O objetivo passa de facto por escrever uma história que reabre para os descendentes de escravos, a possibilidade de voltarem a ser agentes da própria história. No prolongamento da Emancipação e da Reconstrução, a reescrita da história é, mais do que nunca, considerada um acto de imaginação moral (MBEMBE, 2014, p. 60).

Ao falar que a estrutura dessa performance deve seguir uma ordem teológica, Mbembe pensa justamente na dimensão ética e política da temporalidade. O próprio uso dos termos "emancipação", "reconstrução" concedem às demandas de justiça e democracia do presente uma (re)imaginação moral do passado. Do estatuto de escravo ao de cidadão, o devir-negro do mundo em sua dimensão ética busca estender seu projeto político a outras vidas em situação de precariedade em escala global, de forma a conceber uma nova comunidade dos despossuídos ${ }^{x i i i}$. 
Do mesmo modo, ao adicionar novas definições a essa segunda escritura, Mbembe faz uso de diversas metáforas: "é fruto de uma longa história da radicalidade, germinada nas lutas abolicionistas e na resistência ao capitalismo" (MBEMBE, 2014, p. 62); "ele [o escravo] testemunha uma humanidade mutilada, profundamente marcada pelo ferro da alienação" (ibidem, p. 73); figuras de linguagem que ressaltam o caráter traumático e persistente dessas feridas históricas e da resistência no seu interior mesmo. Daí porque, "a revolta dos escravos" - o temor de uma nova revolução haitiana assombre a modernidade.

Não chega a causar espanto que imediatamente após suas considerações sobre a dimensão performativa dessa segunda escrita, Mbembe decida tomar a ficção negra contemporânea para pensar sobre as linguagens da recordação:

No romance negro, tudo parece indicar que o tempo não é um processo que podemos limitar-nos a registrar sob a forma, por exemplo, de uma "sucessão de instantes". Por outras palavras, não existe tempo em si. O tempo nasce da relação contingente, ambígua e contraditória que mantemos com as coisas, com o mundo e, até, com o corpo e os seus duplos (...) a crítica do tempo tal como se desenrola na ficção negra contemporânea ensina-nos igualmente que o tempo é sempre aleatório e provisório. Vai mudando indefinidamente, e as suas formas são sempre incertas. Consequentemente, representará sempre uma região heterogênea, irregular, e fragmentada da experiência humana. Sendo assim, a relação do sujeito com o tempo é uma relação que não tenta, necessariamente, esquivar-se ao passado e ao futuro, mas pelo menos resgatá-los e subsumi-los (MBEMBE, 2014, p. 208-209).

Esse modelo temporal tomado como exemplo por Achille Mbembe comporta notáveis similaridades com o tempo espectral de Jacques Derrida, especialmente no que diz respeito ao seu caráter incerto, provisório, aleatório. Na espectrologia de Derrida, não há uma oposição sistemática entre a morte e a vida, entre o passado e o presente. $\mathrm{O}$ passado, aqui, vive indiretamente no presente, envolvendo-o e dando-lhe forma, mais que o determinando (DERRIDA, 1994). Como bem notou Wendy Brown:

O espectro inverte a compreensão habitual da história como origem (e do presente como seu fruto teleológico) por ser perenemente um revenant [fantasma, em inglês], um retornado. $\mathrm{O}$ espectro começa retornando, repetindo-se, repetindo-se no presente (...) opera como força. Além disso, não podemos controlar o ir e vir dos espectros porque sua aparição é por natureza "furtiva e intempestiva"; os espectros agitam o tempo, da mesma forma que a justiça deve implicar um incômodo ao presente, um regresso do presente até nossos 
ancestrais, e adiante até quem ainda não nasceu. (BROWN, 2014, p. 210).

As proximidades com a espectrologia derrideana deixam a parte final de Crítica da Razão Negra ainda mais ensaística, performativa. Algo demonstrado no trecho: "existe alguma coisa no nome que julga o mundo e que apela à reparação, restituição e justiça". Mas, qual modelo de justiça? Que o termo "julga" apareça grifado nesse momento do texto serve para pensar o quanto para Achille Mbembe importa uma noção de justiça muito próxima da descrição da justiça derrideana efetuada por Wendy Brown:

As formulações da justiça propostas por Derrida rompem com as convenções habituais da teoria política. Tem escassa relação com uma definição distributiva, não é tampouco de procedimento, orientada aos direitos, articulada pela lei e ligada a medidas de participação ou de poder compartilhado. Em vez disso, a justiça termina sendo mais temporal que institucional ou espacial: está relacionada quase por completa com uma prática de relações responsáveis entre gerações. (...) A justiça não tem a ver apenas com nossa dívida com o passado, mas também com alguma herança do passado no presente: esta não só dá forma a nossa obrigação para o futuro, mas também a nossa responsabilidade por nossa presença (fantasmal) nesse futuro. (BROWN, 2014, p. 216).

Operar - na política, na escrita da história - é o dever ético central desenvolvido por Achille Mbembe. É o devir-negro do mundo. É entender a "presença espectral do nome [Negro] no mundo [neoliberal]". Pois, o nosso mundo: "continua a ser, mesmo que ele não queira admiti-lo", um mundo de raças. A verdadeira promessa (novamente no sentido de Derrida), a crítica da modernidade, permanecerá inconclusa conquanto não compreendamos a proximidade do seu advento com a lógica racial. Daí porque, o Negro descrito por Mbembe no final de A Crítica da Razão Negra seja tão fantasmático: sujeito que fugiu da morte e regressou dos mortos, da morte-em-vida do regime colonial. Aniquilado, coagido com a perda de suas raízes, de sua história, fará, apesar de tudo, surgir de tal acontecimento uma identidade outra. Funcionando em outras temporalidades:

Em primeiro lugar, no paradigma fantasmal, não existe reversibilidade nem irreversibilidade do tempo. O que conta é o desenrolar da experiência. As coisas e os acontecimentos envolvem-se uns aos outros. Se as histórias e os acontecimentos têm um princípio, não precisam de um fim propriamente dito. Podemos, certamente, ser interrompidos. Mas uma história ou um acontecimento são capazes de 
prosseguir numa outra história ou num outro acontecimento, sem que haja necessariamente um encadeamento entre ambos. Os conflitos e as lutas podem ser retomados no ponto em que ficaram suspensos. Podese também retomá-los ou ainda assistir-se a novos começos, sem que se sinta falta de continuidade, ainda que a sombra das histórias e dos acontecimentos antigos paire sempre no presente. (...) Dito isso, a relação entre o presente, o passado e o futuro não é nem da ordem da continuidade nem da ordem da genealogia, mas da do encadeamento de séries temporais praticamente dissociadas, ligadas umas às outras por uma multiplicidade de fios tênues (MBEMBE, 2014, p. 251).

Para Mbembe, por fim, insistir nessa performatividade, nessa política do tempo, cumpre um duplo papel ético: busca redimir no presente sujeitos históricos triturados pela maquinaria da atribuição de raça, ao mesmo tempo em que faz desses pedaços a razão - uma nova razão, uma razão negra - de ser dos projetos emancipatórios do porvir.

$I V-\operatorname{Cod} a$

Voltemos agora ao ano de 2008. Do pânico causado pelo colapso do sistema financeiro global precipitado pela falência do banco de investimento americano Lehman Brothers (e o de outras importantes instituições financeiras pelo mundo), em setembro, à empolgante vitória de Barack Obama, o primeiro presidente negro dos Estados Unidos, em novembro, vemos surgir um conjunto de curiosas expectativas sobre os próximos anos.

O projeto teórico de Achille Mbembe procura atuar a partir dos efeitos desses dois eventos. Pois a consequente precarização pós-crise financeira possui uma "linha de cor" que faz da tese de que a eleição de Obama inaugurou uma "era pós-racial” um devaneio neoliberal. Os Negros de Mbembe são vidas precárias (BUTLER, 2015, p. 13-55), vivendo em uma "experiência do tempo precária": um tempo de aceleração constante, "curto-prazismo", imprevisibilidade, precarização do rendimento financeiro, perda do vínculo de solidariedade social, trabalhos temporários, a falta de expectativas e a paradoxal necessidade de requalificação permanente. Uma experiência do tempo característica da "Nova Razão do Mundo" (2016) com sua racionalidade empresarial.

Contra esse modelo concorrencial que delimita novos "condenados da Terra", ou seja, grupos a quem é recusado a possibilidade de ter direitos, de se manifestar; contra essa racionalidade que utiliza-se das mais distintas estruturas de reclusão - campos de concentração, prisões de passagem - para os deportados, clandestinos, "sem-papéis", 
para os corpos que não são passíveis de luto; Mbembe propõe um humanismo planetário, o afropolitanismo, ou seja, a luta por um mundo verdadeiramente comum:

O peso da história encontra-se aí. É preciso aprender a carregar e a repartir o seu peso de uma maneira mais eficaz. Estamos condenados a viver não apenas com aquilo que produzimos, mas também com o que herdámos, e devemos aprender a viver tudo isso em liberdade. Uma vez que não saímos inteiramente de uma mentalidade dominada ainda pela ideia da selecção entre diferentes tipos de seres humanos, é preciso trabalhar com e contra o passado, de maneira a que este possa abrir-se para um futuro comum, com dignidade para todos. O caminho passa pela produção, a partir da crítica do passado, de um futuro indissociável de certa ideia de justiça, da dignidade e do em comum (MBEMBE, 2014, p. 296).

Para além da proximidade que a ideia de comum proposta por Mbembe possui com a teoria política de Jean-Luc Nancy (2000) essa noção de "peso da história", de "trabalhar com e contra o passado" aproxima o projeto político e temporal proposto por Mbembe da atuação do Black Lives Matter ${ }^{\mathrm{xiv}}$, na medida em que esse movimento social norte-americano trabalha retomando preceitos do Movimento pelos Direitos Civis da década de 1960-1970, como ocupação de espaços públicos e a luta contra o racismo institucional, ao mesmo tempo em que rompe com outras diretrizes tracionais: lideranças heterossexuais masculinas, nacionalismo negro, etc. $\mathrm{O}$ ideal de justiça do Black Lives Matter, sua demanda de reparação histórica, aproxima-se do devir negro do mundo de Mbembe ao desejar ser uma luta em escala global e inclusiva: ao Black Lives Matter interessa fortalecer alianças entre os grupos precarizados pela violência policial e as governabilidades neoliberais, seja lutando em conjunto com os indígenas contra a construção de um gasoduto na reserva Sioux de Standing Rock, seja no diálogo crescente com os Comitês pela Liberdade de Rafael Braga no Brasil, etc.

Como vimos, começar por uma crítica ao tempo linear e disciplinado da história é um primeiro pressuposto. De igual maneira, ressaltar o caráter performativo do tempo histórico é uma demanda epistemológica urgente para refletir sobre as consequências políticas e éticas do discurso historiográfico.

\section{Referências}

AUSTIN, J. L. Quando dizer é fazer: palavras e ação. Porto Alegre: Artes Médias, 1990;

ÁVILA, Arthur de Lima. "Povoando o presente de fantasmas": feridas históricas, passados presentes e as políticas do tempo de uma disciplina. Expedições: Teoria e História da Historiografia, v.7, p. 189-209, 2016. 
BALLESTRIN, Luciana. América Latina e o giro decolonial. Revista Brasileira de Ciência Política, v. 2, p. 89-117, 2013.

BENJAMIN, Walter. Teses sobre o conceito de História. In: Magia e Técnica, Arte e Política - Ensaios sobre literatura e história da cultura. São Paulo: Brasiliense, 1987, p. 222-235.

BEVERNAGE, Berber, LORENZ, Chris. Breaking up Time. Negotiating the Borders between Present, Past and Future. Storia della Storiografia, 63. 1/2013.

BEVERNAGE, Berber. Historia, memoria y violencia estatal. Tiempo y justicia. Prometeo. Buenos Aires, 2015.

BROWN, Wendy. La Política Fuera de la Historia. Enclave de Libros, Madrid, 2014.

BUALA. A Europa já não é mais o centro de gravidade do mundo - Entrevista de Arlette Farge com Achille Mbembe. Disponível em: <http://www.buala.org/pt/cara-acara/a-europa-ja-nao-e-o-centro-de-gravidade-do-mundo $>$ acessado em 18/07/2017.

BURKE, Peter. O que é História Cultural? Editora Zahar, Rio de Janeiro, 2008.

Performing History: The Importance of Ocasions. The Journal of Theory and Practice, vol. 9, 2005, p. 35-52.

BUTLER, Judith. Introdução: Vida precária, vida passível de luto. In: Quadros de Guerra. Quando a vida é passível de luto? Civilização Brasileira, Rio de Janeiro, 2016. p. $13-56$.

Cuerpos Aliados y lucha política. Hacia una teoria politica de la assemblea. Barcelona, Paidós, 2017.

BUTLER, Judith; ATHANASIOU, Athena. Desposesión: lo performativo en lo político. Tradución de Fernando Bogado. Buenos Aires: Eterna Cadencia Editora, 2017. CERTEAU, Michel de. História e Psicanálise: entre a ciência e a ficção. Autêntica Editora, Belo Horizonte, 2011.

CHAKRABARTY, Dipesh. Provicializing Europe. Postcolonial Thought and Historical Difference, Princeton University Press, Princeton, 2000.

History and the politics of recognition. In: JENKINS,

Keith; MORGAN, Sue; MUNSLOW, Alun (Org.) Manifestos for History. London: Routledge, 2007. p. 77-87.

DARDOT, Pierre; LAVAL, Christian. A Nova Razão do Mundo - ensaio sobre a sociedade neoliberal. Boitempo Editorial. São Paulo. 2016.

DERRIDA, Jacques. Espectros de Marx. Rio de Janeiro: Relume-Dumará, 1994.

HARTOG, François. Regimes de Historicidade. Presentismo e Experiência do Tempo. Autêntica Editora, Belo Horizonte, 2013.

HUYSSEN, Andreas. Seduzidos pela Memória - arquitetura, monumentos, mídia. Rio de Janeiro: Aeroplano, 2000.

JASMIN, Marcelo. História dos conceitos e teoria política e social: referências preliminares. Revista Brasileira de Ciências Sociais, São Paulo, v. 20, n. 57, p. 27-38, 2005.

KOSELLECK, Reinhardt. Futuro Passado: contribuição à semântica dos tempos históricos. Rio de Janeiro: Contraponto Editora, 2006.

LORENZ, Chris. History and Theory. In: SCHNEIDER, Axel; WOOLF, Daniel (orgs.) The Oxford History of Historical Writing. Volume 5: Historical Writing Since 1945. Oxford University Press, 2015, p. 13-35.

MBEMBE, Achille. Crítica da Razão Negra. Antígona, Lisboa, 2014.

MIRZOEFF, Nicholas. Below the Water: Black Lives Matter and Revolutionary Time. Journal \#79. February 2017. Disponível em: < http://www.eflux.com/journal/79/94164/below-the-water-black-lives-matter-and-revolutionary-time/ $>$ acessado em 25/06/2017. 
MUDROVCIC, Maria Inés. La Nación, el Tiempo Histórico y la Modernidad: la historia como sintoma. Revista de la Facultad de Filosofia, Ciencias de la Educación y Humanidades. Buenos Aires, 2012, p. 25-38.

NANCY, Jean-Luc. La comunidad inoperante. Santiago de Chile: Arcis, 2000.

PAUL, Herman. Performing History: How Historical Scholarship is Shaped by Epistemic Virtues. History and Theory, 50, no.1, 2011, p. 1-19.

SANCHEZ-PIETRO. Los desafios del "giro performativo": el modelo de Alexander y la perviviencia de Turner. In Oncina, Faustino y Elena Cantarino (coords.), Giros narrativos e historias del saber, Madrid: Plaza y Valdés, 2013, p. 77-110.

TANDING, Guy. O precariado: a nova classe perigosa. Belo Horizonte: Autêntica, 2014.

WHITE, Hayden. O Evento Modernista. Revista Lugar Comum. n ${ }^{\circ}$ 5-6, p. 191-219, UFRJ, 1999.

WINTER, Jay. Introduction. The performance of the past: memory, history, identity. In: TILMANS, Karin; VREE, Frank van; WINTER, Jay (Org.). Performing the past: memory, history, and identity in modern Europe. 1. Ed. Amsterdã: Amsterdam University Press, 2010. p. 11-34.

\footnotetext{
${ }^{\mathrm{i}}$ Todas as citações de textos em espanhol ou inglês foram traduzidas pelo autor como forma de agilizar a leitura do texto.

ii De acordo com Luciana Ballestrin (2013) o termo "pós-colonialismo" abarca dois entendimentos. O primeiro, está relacionado ao tempo histórico posterior à descolonização do chamado "terceiro mundo", a partir da metade do século XX. O segundo entendimento diz respeito às contribuições teóricas advindas em grande parte dos estudos literários e culturais, que a partir dos anos 1980 começam a ficar em evidencia em universidades inglesas e americanas com uma epistemologia crítica às narrativas dominantes da modernidade.

iii $\mathrm{O}$ conceito de flecha do tempo se refere à direção que o mesmo executa, ininterruptamente, do passado até o futuro, de forma irreversível.

${ }^{\text {iv }} \mathrm{Na}$ definição de Hartog: "o regime de historicidade se pretenderia uma ferramenta heurística, ajudando a melhor apreender, não o tempo, todos os tempos ou a totalidade do tempo, mas principalmente momentos de crise do tempo, aqui e lá, quando vêm justamente perder sua evidência as articulações do passado, do presente e do futuro" (HARTOG, 2013, p. 37).

v Semelhante raciocínio é proposto por Andreas Huyssen (2000), em Seduzidos pela Memória.

${ }^{v i}$ É interessante notar aqui a referência que Hartog faz ao sociólogo Robert Castel, associando a experiência do tempo particular dos sujeitos precarizados. Algo muito próximo das análises de Guy Standing (2014), em $O$ Precariado: a nova classe perigosa; além de Pierre Dardot e Christian Laval (2016), em A Nova Razão do Mundo - ensaio sobre a sociedade neoliberal. Obras que dialogam frontalmente com o proposto por Achille Mbembe.

vii Conforme sua descrição, o "ocasionalismo" indicaria que: "em diferentes ocasiões (momentos, locais) ou em diferentes situações, na presença de diferentes pessoas, o mesmo indivíduo comporta-se de modo diverso". (BURKE, 2004, p. 125).

viii Trata-se de uma obra referência no que diz respeito à ideia de performatividade do passado, sobretudo em como aplica essas reflexões em estudos sobre comemorações cívicas, imagens, história oral, música, literatura, história nacional, museus etc.

ix - Todavia, Bevernage faz questão de ressaltar que: "embora algumas frases e maneiras de se expressar possam apontar em outra direção, não é minha intenção sugerir que os membros da TRC usaram conscientemente o discurso histórico por causa de seu potencial performativo ou estivessem conscientemente envolvidos em uma política de tempo com o objetivo de restaurar o senso moderno de uma ruptura entre o passado e o presente e assim declarar fora do tempo as vítimas não cooperativas. Embora eu acredite que a performatividade discursiva e a política temporal podem ter consequências reais, desejáveis e indesejáveis, esta performatividade se refere mais aos efeitos do que às intenções" (BEVERNAGE, 2015, p. 130). Porém, como vimos (ao final do subtópico 1), em Breaking Up Time Negotiating the Borders between Present, Past and Future, escrito em 2013 (ou seja, um ano após a publicação original de Historia, memoria y violencia estatal, pela editora Routledge) junto com Chriz Lorenz, o mesmo Bevernage iria radicalizar essa abordagem da performatividade, ao questionar se
} 
enquanto historiadores poderíamos pensar o passado em termos de "intervenção performativa" LORENZ; BEVERNAGE; 2013, p. 29-30.

${ }^{x}$ Embora seu campo de atuação atualmente gire em torno da filosofia política, o camaronês Achille Mbembe possui formação em história. Para ele, Critica da Razão Negra "serve-se da história para propor um estilo de reflexão crítica do mundo do nosso tempo" (MBEMBE, 2014, p. 21).

xi Não por coincidência, nesse instante, em sua primeira nota de rodapé, há menção ao texto Provincializinp Europe. Postcolonial Thought and Historical Difference, de Dipesh Chakrabarty (2000).

xii Como recorda Sheldon Wolin "um tempo de incessantes mudanças é também um tempo saturado de perdas". (op. cit. BROWN, 2014, p. 201).

xiii Há uma grande aproximação de Mbembe com o pensamento de Judith Butler (os dois, inclusive, participam de diversos eventos em comum), especialmente nos estudos que essa autora realiza sobre o que seriam "vidas precárias" a partir de uma leitura da ética de Emmanuel Levinas como forma de inaugurar novas possibilidades políticas frente ao avanço das governabilidades neoliberais. Cf. BUTLER, Judith. Cuerpos Aliados y lucha política. Hacia una teoria politica de la assemblea. Barcelona, Paidós, 2017 e BUTLER, Judith; ATHANASIOU, Athena. Desposesión: lo performativo en lo político. Tradución de Fernando Bogado. Buenos Aires: Eterna Cadencia Editora, 2017.

xiv O Black Lives Matter (As Vidas Negras Importam) é um movimento social norte-americano, que surgiu através de hashtags com ampla divulgação na Internet após episódios de violência policial contra jovens negros no ano de 2013. Atualmente, seus ativistas organizam protestos em torno da morte de negros advindas da brutalidade policial, o racismo do sistema prisional americano, justiça histórico reparativa, além de questões mais amplas que envolvem outros grupos precarizados em escala global. 